УДК 330:656.2

\title{
РОЗРОБЛЕННЯ МЕТОДИКИ ОЦНЮВАННЯ РІВНЯ ЛОКАЛІЗАЦІЇ ВИРОБНИЦТВА ДЛЯ РЕАЛІЗАЦІЇ ІНФРАСТРУКТУРНИХ ПРОЕКТІВ НА ЗАЛІЗНИЧНОМУ ТРАНСПОРТІ
}

\author{
Корінь М.В., к.е.н., доцент, \\ Васильев О.В., махістр, \\ Скубяк О.О., махістр (УкрДУЗТ)
}

\begin{abstract}
В статті вивчено існуючі підходи до оцінювання рівня локалізації. Встановлено існування чотирьох основних підходи до оцінювання рівня локалізачії, щуо передбачають проведення оцінки рівня локалізачія з урахуванням фонду заробітної плати, вартості сировини, матеріалів, комплектуючих, обладнання та нематеріальних активів або розміру статутного капіталу. Розроблено методичний підхід до оцінювання рівня локалізації виробництва для реалізації проєктів розвитку інфраструктури залізничного транспорту в умовах транскордонної співпраці, який трунтується на концепиіі життєвого ичиклу інфраструктурного проєкту $i$ передбачає поетапний розрахунок інтегрального показника, щуо враховує рівень локалізації виробнищтва на кожній фазі його реалізачіï.
\end{abstract}

Ключові слова: інфраструктурний проєкт, локалізація виробництва, залізничний транспорт, методика оцінювання.

\section{РАЗРАБОТКА МЕТОДИКИ ОЦЕНКИ УРОВНЯ ЛОКАЛИЗАЦИИ ПРОИЗВОДСТВА ДЛЯ РЕАЛИЗАЦИИ ИНФРАСТРУКТУРНЫХ ПРОЕКТОВ НА ЖЕЛЕЗНОДОРОЖНОМ ТРАНСПОРТЕ}

\author{
Коринь М.В., к.э.н, доцент, \\ Васильев А.В., магистр, \\ Скубяк О.А., магистр (УкрГУЖТ)
}

В статье изучень существующие подходь к оценке уровня локализачии. Установлено существование четырех основных подхода к оценке уровня локализаџии, которые предусматривают проведение оченки уровня локализачии с учетом фонда заработной платы, стоимости сырья, материалов, комплектующих, оборудования и нематериальных активов, размера уставного капитала. Разработан методический подход к оченке уровня локализачии производства для реализаџии проектов развития инфраструктуры железнодорожного транспорта в условиях трансграничного сотрудничества, который основывается на конщепции жизненного иикла инфраструктурного проекта и предусматривает поэтапньй расчет интегрального показателя, который учитывает уровень локализации производства на каждой фазе его реализачии .

Ключевые слова: инфраструктурный проект, локализация производства, железнодорожный транспорт, методика оценки.

(C) Корінь M.В.,

Васильєв О.В.,

Вісник економіки транспорту і промисловості № 68, 2019

Скубяк O.O. 


\title{
DEVELOPMENT OF A METHODOLOGY FOR ASSESSING THE LEVEL OF LOCALIZATION OF PRODUCTION FOR THE IMPLEMENTATION OF INFRASTRUCTURE FACILITIES ON RAIL TRANSPORT
}

\author{
Korin M., candidate of economic sciences, associate professor, \\ Vasilyev A., master, \\ Skubak O., master (USURT)
}

The article examines the existing approaches to assessing the level of localization. There are four main approaches to assessing the level of localization, taking into account the industry specifics and the level of resource potential of enterprises and provide for the assessment of the level of localization, taking into account the salary Fund, the cost of raw materials, components, equipment and intangible assets and the size of the authorized capital. Determined that to assess the level of localization of production in the implementation of infrastructure projects of railway transport in cross-border regions requires a method of estimating the level of localization of production in projects of development of railway infrastructure, which involves integrated indicator of an assessment of the level of localization, reflecting the current level of localization for each execution phase of infrastructure projects. On this basis, a methodological approach to assessing the level of localization of production for the implementation of projects for the development of railway infrastructure in the context of cross-border cooperation has been developed, which is based on the concept of the life cycle of an infrastructure project and provides for a phased calculation of an integral indicator that takes into account the level of localization of production at each phase of its implementation. Stages of carrying out and the system of indicators of an assessment of level of localization of production for implementation of projects of development of infrastructure of railway transport within cross-border regions is revealed. It is proved that the use of this technique allows to establish the level of import dependence of railway transport at each stage of the infrastructure project and measures to enhance the participation of domestic enterprises in their implementation.

Keywords: infrastructure project, localization of production, railway transport, evaluation methodology.

Постановка проблеми. Ключовою вимогою сучасних споживачів послуг залізничного транспорту $\epsilon$ зручність та швидкість перевезень. На жаль попри активні заходи галузі в напрямку підвищення якості залізничних перевезень АТ «Укрзалізниця» технологічно не має змоги прискорити швидкість обслуговування пасажирів i вантажовідправників. Це зумовлено як високим рівнем зношеності об'єктів залізничної інфраструктури, так i експлуатаційною несумісністю 3 залізницями $\mathrm{\epsilon C}$, що обмежує швидкість перевезень та через різні стандарти колії не дозволяє забезпечити безперебійне сполучення. Для підтримки інтероперабельності 3 залізницями країн Європи наразі на залізничному транспорті необхідно забезпечити як будівництво окремої залізничної інфраструктури, призначеної для руху високошвидкісних поїздів, так і створення цілого комплексу об'єктів транспортно-логістичного обслуговування 3 метою прискорення процесів переробки вантажів.

Інтегруючись в транспортний простір ЄС, АТ «Укрзалізниця» має змогу не лише покращити транспортне сполучення, але й отримати доступ до інноваційних технологій та інвестицій транскордонних європейських країн, що

Вісник економіки транспорту і промисловості № 68, 2019 
можливо забезпечити за рахунок поглиблення транскордонного співробітництва i розвитку на цій основі локалізованих виробництв.

Однак вибір механізмів розвитку локалізації виробництва 3 метою забезпечення реалізації інфраструктурних проєктів залізничного транспорту в рамках транскордонних регіонів потребує встановлення прийнятного рівня локалізації, що актуалізує необхідність вивчення існуючих підходів до його оцінювання.

Аналіз досліджень та публікацій. Обгрунтуванню доцільності розвитку локалізованих виробництв для відродження економічного потенціалу України та розробленню методик оцінювання рівня локалізації виробництва приділили свої наукові праці такі вчені вітчизняної та закордонної наукових шкіл, як В.К. Акінфієва, А.М. Ваз'янський, В. Л. Дикань, М.В. Корінь, В.Ю. Маркова, I.В. Токмакова, Д.Г. Шувалова та інші [15]. Попри вагомість наукових розробок даних вчених для створення передумов розвитку локалізованих виробництв в Україні, необхідність реалізації масштабних інфраструктурних проєктів розвитку залізничного транспорту актуалізуе завдання обгрунтування економічно доцільного рівня локалізації виробництва в процесі їх виконання та обумовлює необхідність розроблення відповідної методики оцінювання.

Мета статті. Тому, метою статті $\epsilon$ вивчення існуючих підходів до оцінювання рівня локалізації і розроблення на цій основі методики оцінювання рівня локалізації виробництва для реалізації проєктів розвитку інфраструктури залізничного транспорту в умовах транскордонної співпраці.

Виклад основного матеріалу. 3 теоретичної точки зору термін «локалізація» означає зосередження чого або когось на певній території. Згідно 3 визначенням, наведеному у Словнику іншомовних слів, локалізація означає віднесення чого-небудь до певної території, a отже, даному процесу властивим $\epsilon$ обмеження місця дії та впливу [6]. Локалізація виробництва, на думку A.M. Ваз'янського, означає процес виробництва продукції на території іншої країни, що має іноземне походження [2]. На думку В.К. Акінфієва, локалізація виробництва пов'язана 3 процесом переміщення на територію певної країни технологій і виконання заходів 3 їхньої адаптації, організації збирального виробництва закордонних зразків за умови часткового виробництва деяких комплектуючих на даній території [1].

Наразі АТ «Укрзалізниця» досить активно застосовує механізм локалізації виробництва для оновлення парку рухомого складу. Зокрема, в рамках виконання проєкту співпраці 3 компанією «General Electric», що передбачає дооснащення вантажних дизельних локомотивів на потужностях ПАТ «Крюковський вагонобудівний завод» з рівнем локалізації 10 \% в Україні, вже наразі в АТ «Укрзалізниця» введено в експлуатацію 30 тепловозів [7]. Детальне ознайомлення 3 публікаціями, які присвячені висвітленню питання розвитку співпраці АТ «Укрзалізниця» на засадах локалізації, дозволило встановити відсутність єдиної методики визначення рівня локалізації виробництва на підприємствах залізничного транспорту i дійти висновку, що рівень локалізації узгоджується окремо для кожного проєкту співпраці на основі взаємних домовленостей. Враховуючи відсутність в АТ «Укрзалізниця» методики розрахунку рівня локалізації виробництва для реалізації проєктів технічного переоснащення галузі та стратегічну значущість проєктів розвитку інфраструктури залізничного транспорту для відродження транзитного потенціалу галузі, вважаємо за необхідне зупинитися на характеристиці існуючих підходів до оцінювання рівня локалізації.

Наразі в економічній літературі сформувалося декілька підходів до проведення оцінки рівня локалізації виробництва. Зокрема, найбільш 
поширеною $\epsilon$ методика оцінки рівня локалізації, розроблена АТ «Інтер РАО Електрогенерація», що передбачає окремо розрахунок рівня локалізації для готової продукції, робіт / послуг та робіт/ послуг, що надаються однією організацією, а також програми закупівель. Зокрема розрахунок рівня локалізації виробництва готової продукції пропонується розраховувати наступним чином [8]:

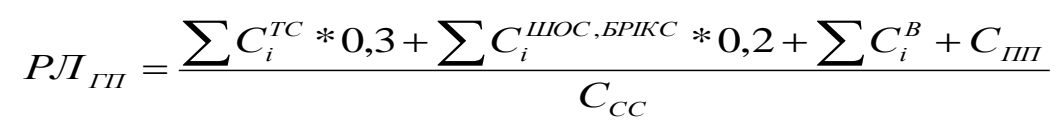

де $C_{i}^{T C}-$ вартість імпортної сировини, основних матеріалів та комплектуючих, країною походження яких держави-члени митного союзу;

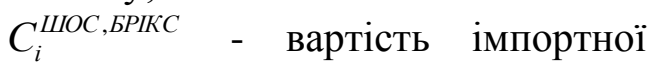
сировини, основних матеріалів та комплектуючих, країною походження яких держави-члени ШОС та БРІКС;

$$
C_{i}^{B} \quad \text { - вартість вітчизняних }
$$

сировини, основних матеріалів та комплектуючих, в тому числі і тих, що набули статусу вітчизняні в результатів додаткової обробки на території країни;

$$
C_{\text {Пп }} \text { - витрати виробничого }
$$

процесу кінцевого виробника 3 виготовлення продукції.

Розрахунок рівня локалізації виробництва робіт пропонується визначати за формулою:

$$
P J_{p}=\frac{K C_{o p 2} * P J_{o p 2}+\sum C_{i} * P J_{i}}{K C P}
$$

де $K C_{\text {орг }}$ - кошторисна собівартість робіт, виконаних організацією;

$P Л_{\text {ор }}$ - рівень локалізації організації; матеріалів;

$C_{i}$ - вартість і-ї позиції обладнання,

$P Л_{i}$ - рівень локалізації і-ї позиції обладнання, матеріалів;

робіт.

КCP - кошторисна собівартість

Рівень локалізації сукупності товарів, технологічно не пов'язаних один 3 одним, але об'єднані в один лот розраховується як відношення сумарного добутку вартості і-го товару (готової продукції, робіт/послуг), що входить до складу лоту і рівня локалізації і-го товару, що входить до лоту, та загальної вартості лоту [8].

Рівня локалізації програми закупівель, що передбачає придбання декількох лотів, визначається за формулою:

$$
\text { РЛ }{ }_{\text {пз }}=\frac{\sum C_{\text {ілот }} * \text { ЕРЛ }{ }_{\text {ілот }}}{\sum B_{\text {пз }}}
$$

де $C_{\text {ілот }}$ - вартість і-го лоту, що входить до складу програми закупівель;

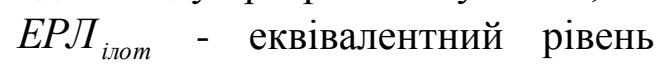
локалізації і-го лоту;

$$
\sum B_{n з} \text { - загальна вартість }
$$

програми закупівель.

Згідно 3 затвердженою Кабінетом Міністрів України методика розрахунку рівня локалізації виробництва підприємствами вітчизняного машинобудування для агропромислового комплексу розрахунок рівня локалізації виробництва пропонується проводити, враховуючи собівартість техніки i обладнання для агропромислового комплексу, яка виробляється на потужностях вітчизняного машинобудування, митну вартість імпортних компонентів та вартість імпортних компонентів, придбаних окремо та/або у складі товару підприємством вітчизняного машинобудування для агропромислового комплексу для виробництва техніки i обладнання у постачальника, який $\epsilon$ резидентом України, без урахування податку на додану вартість [9].

В науковій літературі також існує досить велика кількість методик розрахунку рівня локалізації виробництва. Найбільш поширеною серед них $\epsilon$ 
методика визначення рівня локалізації виробництва продукції на основі митної вартості та ціни продукції. Саме грунтуючись на цій методиці колектив авторів В.Ю. Маркова та Д.Г. Шувалова рівень локалізації пропонують розраховувати [5]:

$$
\text { РЛ }=\frac{\left(1-\frac{V}{P}\right)}{1-\frac{K_{i m n}}{K_{\Sigma}}} * 100
$$

де $V$ - вартість імпортних сировини, матеріалів комплектуючих, технологій нерезидентів;

$P$ - ціна кінцевої продукції;

$K_{i m n}$ - вартість імпортної сировини, матеріалів та комплектуючих, що використовуються в обладнанні та мають вітчизняні аналоги;

$K_{\Sigma}$ - сумарна вартість сировини, матеріалів та комплектуючих, що використовуються в обладнанні.

На основі узагальнення даних по застосовуваних методиках оцінювання рівня локалізації досить цікавим слід виділити спосіб розрахунку, що враховує інформацію бухгалтерського обліку 3 розрахунком собівартості, а також дані щодо приросту інтелектуальної складової виробника електротехнічного обладнання. Оцінювання рівня локалізації проводиться 3 урахуванням таких аспектів діяльності підприємства і характеристик продукції, як наукоємність технологічного процесу, наукоємність та собівартість продукції. При оцінюванні рівня локалізації розраховується обсяг виконаних на території держави розробок (НДДКР) i технологічних операцій. Показник локалізації включає в себе такі складові, як частка нематеріальних активів у майні підприємства, витрати на НДДКР у вигляді приросту складової амортизації нематеріальних активів у собівартості електротехнічної продукції [10] та витрати на виробництво, локалізовані на території держави. Методика дозволяє здійснити комплексне оцінювання рівня локалізації за кожним видом електротехнічного обладнання.

Найбільш прийнятною для АТ «Укрзалізниця» $€$ типова методика визначення рівня локалізації виробництва продукції, що закуповується для потреб холдингу «РЖД». Відповідно до методики 3 метою визначення критеріїв оцінювання фактично досягнутого рівня локалізації виробництва продукції, що закуповується для потреб залізничного транспорту, рівень локалізації визначається за такими групами продукції [11], як:

\begin{tabular}{llr}
\multicolumn{2}{c}{ технічні } & вироби, \\
номенклатура & яких & широко \\
використовується & на & залізничному
\end{tabular} транспорті, технології виробництва яких локалізовані на ряді вітчизняних промислових підприємств. Розрахунок рівня локалізації виробництва продукції по даній групі проводиться відповідно до роботи [11]:

$$
L_{i}=\left(1-\frac{C_{i}}{C C_{i}}\right) x 100 \%,
$$

де $\quad L_{i}-$ рівень локалізації виробництва продукції;

$C_{i}$ - вартість матеріалів і робіт іноземного виробництва, використаних для виготовлення в собівартості продукції;

$C C_{i}$ - собівартість продукції.

рухомий склад, а також кінцева продукція, що належать до категорії складних технічних систем, для виробництва яких використовуються технологічно складні операції, що вимагають наявності високого рівня компетенцій i кваліфікації персоналу, a також використовуються комплектуючі різного рівня від простих до складних. Рівень локалізації продукції визначається відповідно до формули [11]:

$$
L_{i}=\sum\left(D_{o c} x\left(1-\frac{C_{u \wedge n i}}{C C_{c}}\right)\right) x 100 \%
$$

де $\quad L_{i}-$ рівень локалізації продукції;

DoC - відсоткова частка вартості компонентів і робіт у вартості технічної системи без урахування ПДВ; 


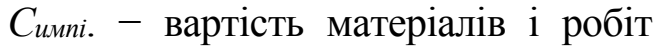
іноземного виробництва, використаних для виготовлення, у собівартості компонентів і робіт, вузлів, деталей і складових частин технічних систем і устаткування;

$C C_{C}$ - собівартість компонентів і робіт, вузлів, деталей і складових частин технічних систем і устаткування.

продукція, при виробництві якої передбачається використання високотехнологічних та інноваційних виробів, а рівень локалізації виробництва розраховується відповідно до такої формули [11]:

$$
L_{i}=\sum_{i=1-3}\left(B_{i} * \frac{M 3_{i}+T 3_{i}+I 3_{i \text { ндДК }}}{C_{\text {ізаг }}}\right) * 100,
$$

де $\quad L_{i}$ - рівень локалізації, \%;

$\mathrm{Bi} \quad-\quad$ середньостатистична розрахункова питома вага технологічної операції в структурі трудомісткості виробництва продукції;

$M 3_{i}$ - матеріальні витрати окремої технологічної операції, виробленої в країні, розраховується на підставі регламентованих документів: карти технологічного процесу, маршрутної карти, відомості складання виробу і відомості матеріалів;

$T 3_{i}$ - витрати на оплату праці в окремій технологічній операції, здійсненій в країні, розраховується на підставі регламентованих документів: карти технологічного процесу, маршрутної карти, відомості складання виробу і відомості матеріалів;

I3i нддкР - витрати на НДДКР і ДКР, придбання патентів, ноу-хау окремої технологічної операції, здійсненої в країні, розраховується на підставі регламентованих документів: карти технологічного процесу, маршрутної карти, відомості складання виробу і відомості матеріалів;

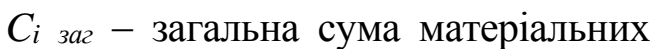
витрат, трудових витрат і витрат на НДДКР і ДКР, придбання патентів, ноу-хау окремої технологічної операції, розраховується на підставі регламентованих документів: карти технологічного процесу, маршрутної карти, відомості складання виробу i відомості матеріалів.

Отже, узагальнюючи варто зазначити, що в цілому в літературі існує значна кількість методик розрахунку рівня локалізації виробництв, що враховують галузеву специфіку та рівень ресурсного потенціалу підприємств. Зокрема в літературі сформувалося чотири основних підходи до оцінювання рівня локалізації: 1) локалізація на рівні фонду заробітної плати; 2) локалізація на рівні сировини , матеріалів, комплектуючих; 3) локалізація на рівні обладнання; 4) локалізація на рівні нематеріальних активів або розміру статутного капіталу [5].

Враховуючи існуючі підходи до оцінювання рівня локалізації виробництва, варто зазначити, що жодна з них є враховує особливості інфраструктурного проєкту, який відрізняється складністю етапів реалізації. Відповідно до цього для оцінювання рівня локалізації виробництва під час реалізації проєктів розвитку інфраструктури залізничного транспорту в межах транскордонних регіонів пропонується в основу методики оцінювання рівня локалізації виробництва під час реалізації проєктів розвитку інфраструктури залізничного транспорту покласти інтегральний показник оцінювання рівня локалізації, що відображатиме досягнутий рівень локалізації на кожній фазі виконання інфраструктурного проєктів [12]:

$$
I_{\text {II }}^{Л B}=\sum_{i=1}^{n} \lambda_{i} \cdot w_{i}
$$

де $\quad \lambda_{i}-$ ваговий коефіцієнт значущості стандартизованих показників оцінювання рівня локалізації виробництва на етапах техніко-економічного обгрунтування, планування і проєктування, виробництва, здачі в експлуатацію проєкту розвитку інфраструктури залізничного транспорту.

$$
w_{i} \text { - стандартизоване значення }
$$

відповідного показника.

Даний методичний підхід грунтується на концепції життєвого циклу 
інфраструктурного проєкту і передбачає оцінювання рівня локалізації виробництва в шість етапів (рис. 1). На першому етапі проводиться постановка завдання оцінювання рівня локалізації виробництва для реалізації проєктів розвитку інфраструктури залізничного транспорту в рамках транскордонних регіонів. Другий етап передбачає розроблення системи часткових показників оцінювання рівня локалізації виробництва на кожній фазі реалізації проєкту (рис. 2).

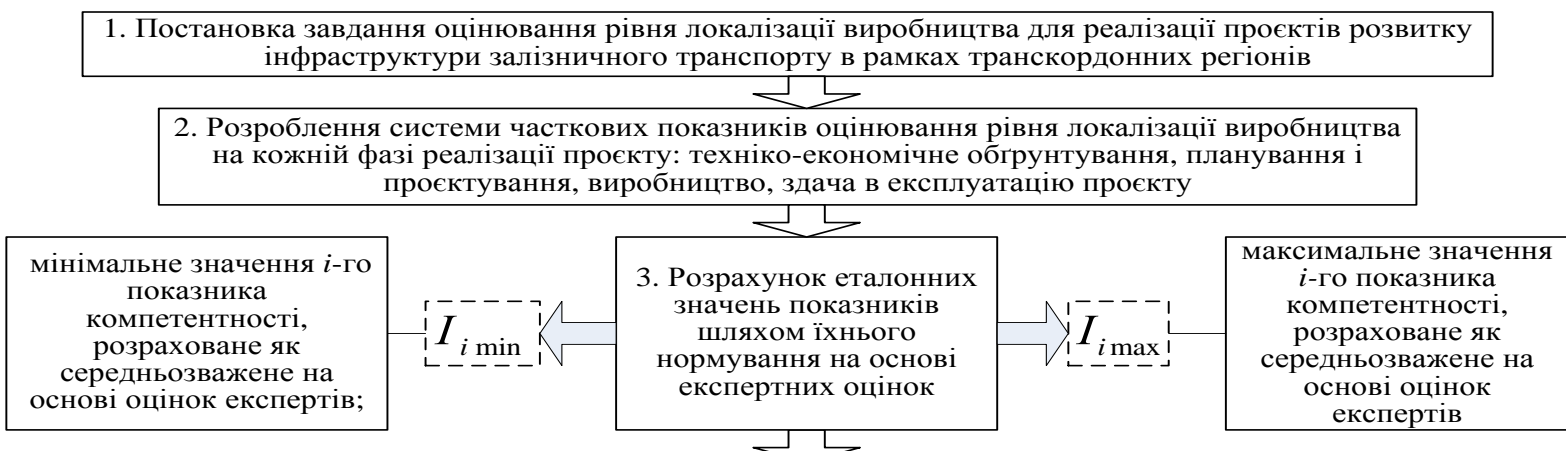

4.Стандартизація вихідних даних показників оцінювання рівня локалізації виробництва на кожній фазі реалізації проєкту відповідно до характеру їхнього впливу

$$
\begin{aligned}
& \text { для показників } \\
& \text { стимуляторів } \\
& w_{i}=\frac{I_{i}-I_{i \min }}{I_{i \max }-I_{i \min }}
\end{aligned}
$$

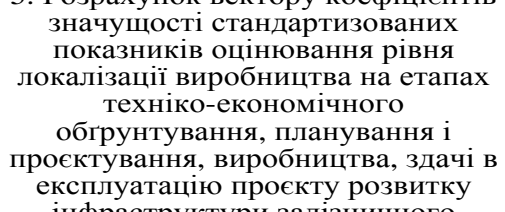

6. Розрахунок інтегрального показника оцінювання рівня локалізації та інтерпретація отриманих його значень

від 0 до 0,25 - низький
рівень - складальне
локалізоване
виробництво

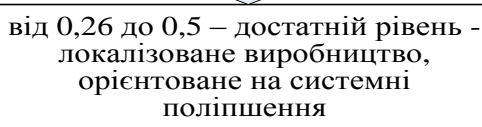
поліпшення

\begin{tabular}{|c|} 
від 0,51 до 0,8 - високий \\
рівень - інноваційно \\
спрямоване локалізоване \\
виробництво \\
\hline
\end{tabular}

Рис.1. Етапи проведення оичнювання рівня локалізації виробництва для реалізачії проєктів розвитку інфраструктури залізничного транспорту в рамках транскордонних регіонів

Третій етап полягає у розрахунку еталонних значень показників шляхом їхнього нормування на основі експертних оцінок. На четвертому етапі проводить стандартизація вихідних даних показників оцінювання рівня локалізації виробництва на кожній фазі реалізації проєкту відповідно до характеру їхнього впливу. На п'ятому етапі проводиться розрахунок вектору коефіцієнтів значущості стандартизованих показників оцінювання рівня локалізації виробництва на етапах техніко-економічного обгрунтування, планування і проєктування, виробництва, здачі в експлуатацію проєкту розвитку інфраструктури залізничного транспорту. Шостий - останній етап - передбачає визначення інтегрального показника та інтерпретацію отриманих його значень. У тому випадку, якщо значення інтегрального показника рівня локалізації виробництва набуває значень: від 0 до 0,25 , то рівень співробітництва можна охарактеризувати як низький - складальне локалізоване виробництво; від 0,26 до 0,5 достатній - локалізоване виробництво, що передбачає системні поліпшення; від 0, 51 до 0,8 - високий - інноваційно спрямоване локалізоване виробництво [12]. 


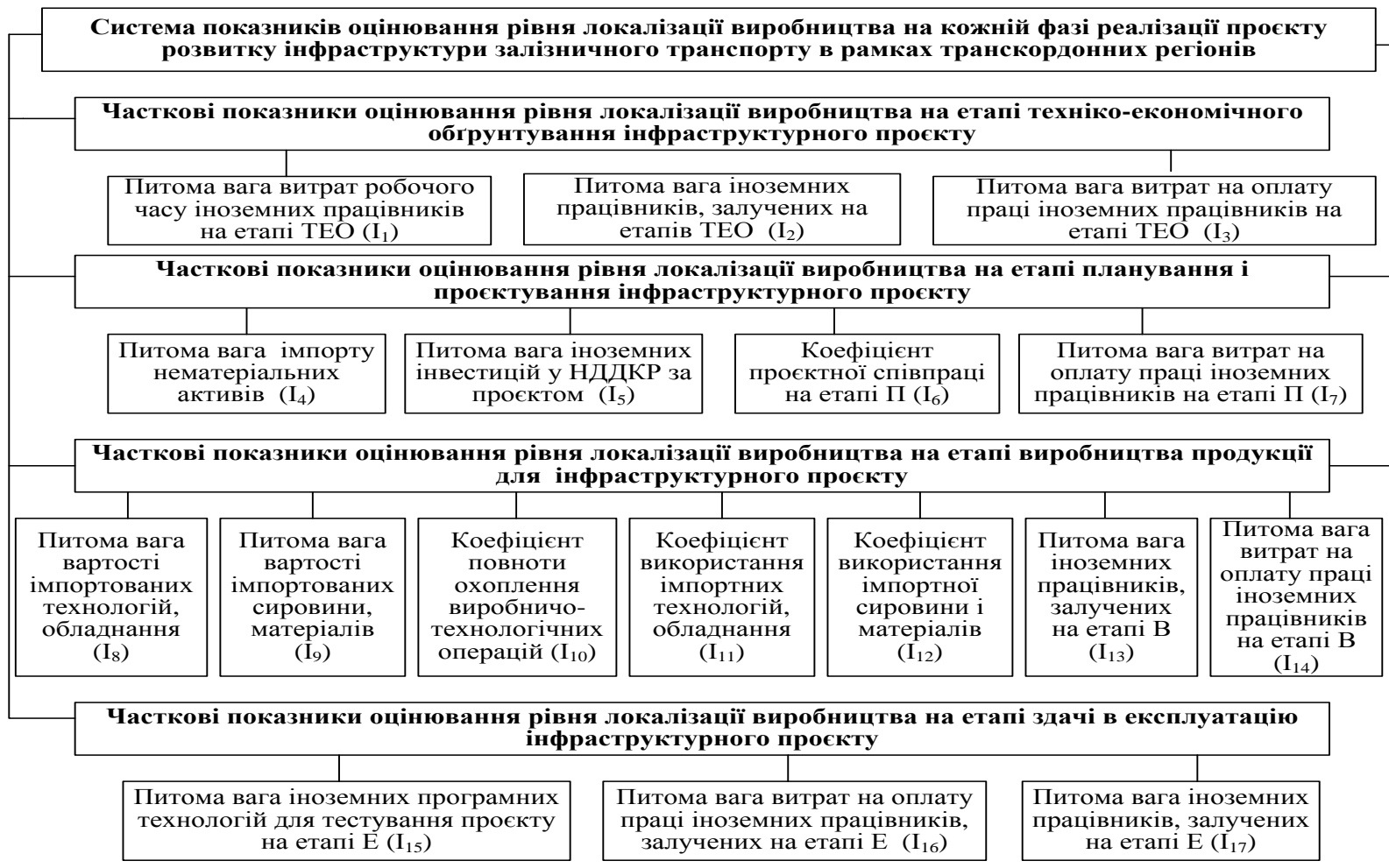

Рис. 2. Система показників очінювання рівня локалізації виробниџтва на кожній фазі реалізації проєкту розвитку інфраструктури залізничного транспорту у рамках транскордонних регіонів

В цілому використання даної методики дозволяє встановити рівень імпортозалежності залізничного транспорту на кожному етапі виконання інфраструктурного проєкту і заходи щодо активізації участі вітчизняних підприємств у їх реалізації.

Висновок. Отже, становлення транскордонного співробітництва на підставі формування локалізованого виробництва 3 розвитку залізничної інфраструктури є платформою для подолання інфраструктурних асиметрій i переходом до цифровізації залізничної галузі та iii високоінтелектуального розвитку. Доцільність локалізації виробництва для задоволення потреб інфраструктурного проєкту в інноваціях потребує встановлення рівня імпортозалежності залізничного транспорту на кожному етапі його реалізації i визначення пріоритетних заходів щодо сприяння наукововиробничої співпраці. Розроблений методичний підхід до оцінювання рівня локалізації грунтується на концепції життєвого циклу інфраструктурного проєкту, відповідно до якої проводиться поетапний розрахунок інтегрального показника, який агрегує оцінки рівня локалізації на кожній фазі реалізації проєкту розвитку інфраструктури залізничного транспорту.

\section{ПЕРЕЛІК ВИКОРИСТАНИХ ДЖЕРЕЛ}

1. Акинфиев В. К. Выбор инвестиционных решений при трансфере западных технологий в отрасли транспортного машиностроения / В. К. Акинфиев // Управление большими системами. - 2014. - Вып. 48. - С. 151-171.

2. Вазьянский А. М. Локализация производства как способ инновационного развития предприятия / А. М. Вазьянский, С. Ю. Обыденнова // Сборник научных трудов НГТУ им. Р. Е. Алексеева. - 2008. № 7. - С. 2.

3. Дикань В. Л. Інжинірингомаркетинговий центр інноваційних 
технологій як основа активізації інноваційно-інвестиційного потенціалу підприємств залізничного транспорту / В. Л. Дикань, І. В. Соломніков // Вісник економіки транспорту та промисловості. 2017. - Вип. 57. - С. 9-20.

4. Токмакова I. В. Теоретикометодологічні аспекти формування інноваційно-промислових кластерів в Україні. Актуальні проблеми та напрями розвитку потенціалу соціальноекономічних систем в умовах конкуренції : монографія / I. В. Токмакова, М. В. Корінь; за заг. редакцією д-ра екон. наук, професора Л. Л. Калініченко. - Харків: ФОП Панов А. М., Видав. дім «В справі», 2017. - С. 48 59.

5. Маркова Ю. В., Шувалова Д. Г. Разработка методики оценки уровня локализации для предприятияй электротехники и энергомашиностроения / Ю. В. Маркова, Д. Г. Шувалова // Научнотехнические ведомости СПбГПУ. Экономические науки. - 2015. - № 6 (233). C. 73-76.

6. Словник іншомовних слів : вебсайт. URL: http://slovopedia.org.ua/36 /53403/243074.html (дата звернення: 19.06.2017).

7. Макряшина В. На КВБЗ - гості. Підприємство урочисто передало Укрзалізниці 30 тепловозів General Electric. URL: http://pplus.in.ua/news/na_kvb gost_p_dpri_mstvo_urochisto_peredalo_uk rzal_znits_30_teplovoz_v_general_electric (дата звернення: 26.11.2019).

8. Методика «Расчет уровня локализации товаров, работ, услу» МТ-0221. URL: https://4science.ru/files /e259001483f841a382025034ba833131.

9. Порядок визначення ступеня локалізації виробництва підприємствами вітчизняного машинобудування для агропромислового комплексу вітчизняної техніки i обладнання для агропромислового комплексу: Постанова Кабінету Міністрів України від 27 травня 2013 р. № 369. Законодавство України : веб-сайт. URL: https://zakon.rada.gov.ua /laws/show/369-2013-\%D0\%BF (дата звернення: 30.08.2018).

10. Шовкун I. А. Локалізація виробництва - світова практика та висновки для України / I. А. Шовкун // Економіка і прогнозування. - 2017. - № 2. - С. 31-56.

11. Типовая методика определения уровня локализации производства продукции, запускаемой для нужд «РЖД»: распоряжение ОАО «РЖД» от 21.04. 2016. № 721 p. URL: tender.rzd.ru/dbmm/download?vp=53

\&load $=\mathrm{y} \&$ col id $=121 \& \mathrm{id}=78968$

(дата обращения: 15.11.2017).

12. Корінь М.В. Розвиток інфраструктури залізничного транспорту в умовах транскордонного співробітництва: монографія / М.В. Корінь. - Харків: УкрДУЗТ, 2019. - 401 с.

\section{REFERENCES}

1. Akynfyev V. K. (2014) Vybor ynvestytsyonnykh reshenyy pry transfere zapadnykh tekhnolohyy v otrasly transportnoho mashynostroenyya [Choice of investment decisions in the transfer of Western technologies in the transport engineering industry]. Upravlenye bol'shymy systemamy. №. 48. pp. 151-171. (in Russian)

2. Vaz'yanskyy A. M., Obydennova S. YU. (2008) Lokalyzatsyya proyzvodstva kak sposob ynnovatsyonnoho razvytyya predpryyatyya [Localization of production as a way of innovative development of the enterprise]. Sbornyk nauchnykh trudov NHTU $y m$. R. E. Alekseeva. № 7. pp. 2. (in Russian)

3. Dykan' V. L., Solomnikov I. V. (2017) Inzhynirynho-marketynhovyy tsentr innovatsiynykh tekhnolohiy yak osnova aktyvizatsiyi innovatsiyno-investytsiynoho potentsialu pidpryyemstv zaliznychnoho transport [Engineering and marketing center of innovative technologies as a basis for activation of innovative and investment potential of railway transport enterprises]. The bulletin of Transport and Industry Economics. №. 57. pp. 9-20. (in Ukrainian)

4. Tokmakova I. V., Korin' M. V. (2017) Teoretyko-metodolohichni aspekty formuvannya innovatsiyno-promyslovykh

Вісник економіки транспорту і промисловості № 68, 2019 
klasteriv v Ukrayini [Theoretical and methodological aspects of the formation of innovation and industrial clusters in Ukraine]. Aktual'ni problemy ta napryamy rozvytku potentsialu sotsial'no-ekonomichnykh system $v$ umovakh konkurentsiyi : monohrafiya / za zah. redaktsiyeyu d-ra ekon. nauk, profesora L. L. Kalinichenko. Kharkiv: FOP Panov A. M., Vydav. dim «V spravi». pp. 48 - 59. (in Ukrainian)

5. Markova YU. V., Shuvalova D. H. (2015) Razrabotka metodyky otsenky urovnya lokalyzatsyy dlya predpryyatyyay élektrotekhnyky y énerhomashynostroenyya [Development of methods for assessing the level of localization for enterprises of electrical engineering and power engineering]. Nauchno-tekhnycheskye vedomosty SPbHPU. Ékonomycheskye nauky. № 6. (233). S. 73-76.

6. Slovnyk inshomovnykh sliv [Dictionary of foreign words]: veb-sayt. URL: http://slovopedia.org.ua/36/53403 243074.html (data zvernennya: 19.06.2017). (in Ukrainian)

7. Makryashyna V. Na KVBZ - hosti. Pidpryyemstvo urochysto peredalo Ukrzaliznytsi 30 teplovoziv General Electric [Visitors are at the KVBZ. The company solemnly handed over 30 General Electric locomotives to Ukrzaliznytsia.]. URL: http://pplus.in.ua/news/na_kvbz__ost_p_dpr i_mstvo_urochisto_peredalo_ukrzal_znits_30_ teplovoz_v_general_electric (дата звернення: 26.11.2019). (in Ukrainian)

8. Metodyka «Raschet urovnya lokalyzatsyy tovarov, rabot, uslu» MT-022-1 [Methodology "Calculation of localization level of goods, works, services" MT-022-1]. URL: https://4science.ru/files/e259001483 f841a382025034ba833131. (in Russian)
9. Poryadok vyznachennya stupenya lokalizatsiyi vyrobnytstva pidpryyemstvamy vitchyznyanoho mashynobuduvannya dlya ahropromyslovoho kompleksu vitchyznyanoyi tekhniky i obladnannya dlya ahropromyslovoho kompleksu [The procedure for determining the degree of localization of production by enterprises of domestic engineering for the agro industrial complex of domestic machinery and equipment for the agro industrial complex]: Postanova Kabinetu Ministriv Ukrayiny vid 27 travnya 2013 r. № 369. Zakonodavstvo Ukrayiny : veb-sayt. URL: https://zakon.rada.gov.ua/laws/show/369-

2013-\%D0\%BF (data zvernennya: 30.08.2018). (in Ukrainian)

10. Shovkun I. A. (2017) Lokalizatsiya vyrobnytstva - svitova praktyka ta vysnovky dlya Ukrayiny [Localization of production-world practice and conclusions for Ukraine]. Ekonomika $i$ prohnozuvannya. № 2. pp. 31-56. (in Ukrainian)

11. Typovaya metodyka opredelenyya urovnya lokalyzatsyy proyzvodstva produktsyy, zapuskaemoy dlya nuzhd «RZHD» [Typical method of determining the level of localization of production launched for the needs of «RZD»]: rasporyazhenye OAO «RZHD» ot 21.04. 2016. № 721 r. URL: tender.rzd.ru/dbmm/download?vp=53 \&load=y\&col_id=121\&id=78968 (data obrashchenyya: 15.11.2017). (in Russian)

12. Korin' M.V. (2019) Rozvytok infrastruktury zaliznychnoho transportu $\mathrm{v}$ umovakh transkordonnoho spivrobitnytstva [Development of railway transport infrastructure in the context of cross-border cooperation]: monohrafiya. Kharkiv: UkrDUZT. 401 s. (in Ukrainian). 